Analisis Persepsi Karyawan ... (Maria K., Prasetya D., dan Dwi I.)

\title{
ANALISIS PERSEPSI KARYAWAN TERHADAP PENERAPAN SISTEM MANAJEMEN KINERJA PT. XYZ
}

\author{
Maria Karmelita D. Sambang, S.Kep, Ns, M.M, \\ PPM School of Management \\ Prasastia Dessy Safrina, S.Kep, Ns, M.M \\ PPM School of Management \\ Dr. Dwi Idawati, M.M \\ PPM School of Management
}

\begin{abstract}
Abstrak
Industri retail fashion accessories saat ini sedang berkembang pesat. Hal tersebut menjadi salah satu peluang bagi PT. XYZ sebagai salah satu pemain di industri tersebut dan menjadikannya sebagai tujuan bisnis perusahaan untuk bisa meraih keuntungan dan menjadi pemain nomor satu di Asia Tenggara. Perusahaan menyadari, untuk bisa mencapai visi dari perusahaan adalah dengan meningkatkan segala macam sumber daya yang ada di perusahaan, salah satunya adalah sumber daya manusia. Melalui sistem yang mampu menilai dan meningkatkan kinerja karyawan, yang biasa disebut dengan istilah manajemen.Oleh karena itu perusahaan meyakini untuk bisa mencapai tujuan perusahaan dibutuhkan sistem manajemen kinerja yang efektif dan efisien. Penelitian ini bertujuan untuk mengidentifikasi persepsi karyawan terhadap penerapan sistem manajemen kinerja PT. XYZ. Jenis penelitian ini applied research dengan menggunakan metode pengumpulan data gabungan metode kuantitatif melalui survei menggunakan kuesioner yang dimodifikasi dari model kuesioner Weiss dan Hartle (1997) untuk mengetahui persepsi karyawan terhadap sistem manajemen kinerja dan metode kualitatif dengan menggunakan wawancara mendalam. Populasi penelitian ini adalah seluruh karyawan kantor pusat PT. XYZ yang berjumlah 315 orang dengan metode non-probability sampling, dengan jenis sampel yang digunakan adalah purpossive sampling sebanyak 104 responden untuk survei dan 3 narasumber untuk wawancara mendalam. Data kuantitatif diolah menggunakan SPSS 22 untuk mencari nilai mean dari setiap tahapan proses manajemen kinerja. Batas minimum suatu sistem manajemen kinerja dikatakan baik adalah nilai mean sebesar 3,20. Sedangkan data kualitatif diolah dengan menggunakan verbatim, reduksi data, intepretasi hasil, dan kesimpulan berdasarkan tahapan proses manajemen kinerja. Hasil penelitian menunjukan bahwa penerapan sistem manajemen kinerja secara keseluruhan belum cukup baik dengan nilai mean sebesar 2,94. Untuk masing-masing tahapan dalam proses manajemen kinerja sendiri menunjukan nilai mean 3,07pada perencanaan, 3,09 pada pelaksanaan, 2,85 pada penilaian, dan 2,75 pada tindak lanjut. Ini menunjukan bahwa sistem manajemen kinerja di PT. XYZ dikategorikan lemah. Hal tersebut juga didukung dari hasil wawancara yang menunjukan bahwa tidak adanya kesepakatan antara atasan dan bawahan mengenai apa yang dilakukan dan dicapai dalam pekerjaan. Sehingga karyawan merasa tidak tahu apa yang harus mereka lakukan dalam pekerjaan, bagaimana cara meningkatkan kinerja, apa yang harus dicapai, dan apa yang akan mereka peroleh ketika mereka mencapai atau tidak mencapai target mereka.
\end{abstract}

Keywords: Retail Fashion Accessories dan Sistem Manajemen Kinerja. 


\section{Journal of Management
and Business Review Vol.13, No.1, January 2016: 88-106}

\section{PENDAHULUAN}

Pertumbuhan Bisnis di era modern ini menjadi salah satu sendi utama pertumbuhan ekonomi global yang kian hari, tingkat persaingan banyak industri yang bermain di dalamnya semakin tinggi. Hal ini tentu didukung oleh tingkat kemajuan ilmu pengetahuan teknologi yang mendorong permintaan akan barang dan jasa yang menjadi unsur utama dalam bisnis semakin tinggi (Aydin, 2010). Salah satu industri yang mempunyai peran besar dalam tingkat pertumbuhan ekonomi global adalah industri retail (Harvard Business Review Analytic Services, 2013).

Di Indonesia sendiri tingkat konsumsi kaum wanita dalam menganggarkan pengeluaran untuk kebutuhan akan fashion dan accessories sangat tinggi. Hal ini didukung oleh data yang dipublikasikan oleh Badan Pusat Statistik (2011) yang menunjukan bahwa pengeluaran rata-rata wanita Indonesia untuk kebutuhan pakaian dan aksesoris sebesar $4.78 \%$ dari total pengeluaran per tahun 2011 .

Sebagai perusahaan yang bergerak dalam bidang fashion dan accessories untuk wanita remaja dan dewasa, PT. XYZ menyadari adanya peluang untuk terus memenuhi permintaan akan kebutuhan konsumen yang terus meningkat seiring dengan peningkatan pertumbuhan ekonomi khususnya pada pemenuhan permintaan barang atau produk fashion dan accessories perempuan dan bahkan PT. XYZ menetapkan target untuk menjadi perusahaan retail fashion dan accessories Nomor 1 di Asia di tahun 2017.

Namun untuk memenuhi Visi, Misi dan target tersebut, saat ini PT. XYZ belum merancang proses perencanaan manajemen kinerja yang berdampak pada tidak sejalannya pada apa yang harus dilakukan dan bagaimana masing-masing karyawan terlibat dalam rencana tersebut dengan tujuan dan sasaran unit kerja, departemen dan perusahaan. Hal ini juga berpengaruh pada proses pelaksanaan manajemen kinerja PT. XYZ yang belum berjalan optimal sebagai dampak lanjutan dari belum diterapkannya perencanaan kinerja yang merupakan rangkaian awal proses manajemen kinerja dalam mencapai tujuan perusahaan. Hal serupa yang digambarkan dalam proses penilaian kinerja yang masih bersifat administratif dan belum adanya panduan yang belum standar dapat berpengaruh terhadap hasil penilaian kinerja karyawan. 
Hal ini besar pengaruhnya terhadap tindak lanjut pengembangan dan pencapaian tujuan individu, unit kerja, departemen dan organisasi sebagaimana yang dijelaskan dalam konsep yang dikembangkan oleh Aguinis (2014) yang menyatakan bahwa, dalam meningkatkan kinerja perusahaan suatu perusahaan harus mampu terlebih dahulu meningkatkan kinerja para karyawannya.

Oleh karena itu, tujuan dari penelitian ini adalah teridentifikasinya persepsi karyawan terhadap sistem manajemen kinerja di PT. XYZ.

\section{LANDASAN TEORI}

\section{Manajemen Kinerja}

Manajemen kinerja merupakan proses yang berkelanjutan mulai dari mengidentifikasi, mengukur, dan mengembangkan kinerja individu dan tim yang sejalan dengan strategi bisnis untuk mencapai tujuan perusahaan (Aguinis, 2014).

Manajemen kinerja juga merupakan aktivitas yang dapat dijadikan landasan untuk memastikan bahwa sasaran organisasi telah dicapai secara konsisten dalam cara-cara yang efektif dan efisien.
Manajemen kinerja bisa berfokus pada kinerja dari suatu organisasi, departemen, karyawan, atau bahkan proses untuk menghasilkan produk atau layanan, dan juga di area yang lain (Brudan, 2010).

Jadi manajemen kinerja merupakan suatu rangkaian proses yang berkesinambungan dan berkelanjutan untuk mengidentifikasi, melakukan pengukuran dan mengembangkan kinerja dalam cakupan tim maupun individu yang diharapkan sejalan dengan strategi perusahaan untuk mencapai tujuan perusahaan.

\section{Proses Manajemen Kinerja}

Ada 6 (enam) kegiatan utama dalam proses manajemen kinerja, yaitu seperti dijelaskan pada Gambar 1 dibawah ini: 


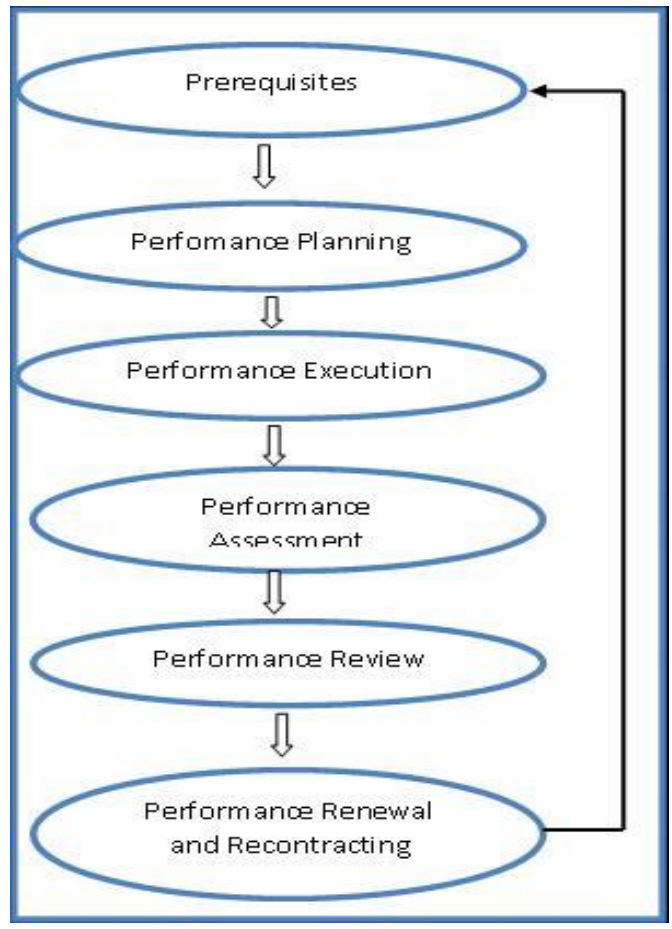

Gambar 1 Kerangka Proses Manajemen

Kinerja

Sumber: Aguinis, 2014

Kerangka diatas menjelaskan mengenai proses manajemen kinerja. Penjelasan mengenai setiap proses akan dibahas dibawah ini.

\section{Prerequisites}

Dalam tahapan pertama ini perusahaan sudah harus mempunyai visi misi yang jelas dan selaras dengan strategic goals, karena apabila visi, misi dan tujuan sebuah perusahaan tidak jelas tentunya akan sulit untuk menentukan tahapan-tahapan selanjutnya (Aguinis, 2014).

2. Performance planning

Pada tahap performance planning, karyawan dan atasan akan mendiskusikan target yang telah ditetapkan sebelumnya serta menetapkan standard target bagi setiap karyawan (Aguinis 2014).

\section{Performance execution}

Di tahap ini, setiap karyawan diharapkan berusaha secara maksimal untuk mencapai tujuan atau hasil yang sudah ditetapkan sebelumnya. Sedangkan dari pihak atasan pada tahap ini bertanggung jawab untuk melakukan coaching dan observasi. Tanggung jawab utamanya selain observasi dan membuat dokumentasi adalah memberikan updates, feedback, resources dan reinforcement (Aguinis, 2014).

\section{Performance assessment}

Pada tahapan ini baik pihak karyawan maupun pihak atasan bertanggung jawab terhadap proses penilaian dan evaluasi untuk mengetahui sejauh mana tujuan yang ditargetkan sudah tercapai dan 
bagaimana proses untuk sampai kepada target tersebut serta bagaimana perilaku yang ditunjukkan (Aguinis, 2014).

\section{Performance review}

Tahapan selanjutnya adalah performance review. Di dalam tahap ini proses yang terjadi adalah pengkajian atau pembahasan mengenai penilaian kinerja dari atasan langsung. Pada tahap ini karyawan akan mendapatkan umpan balik terkait dengan kinerjanya, bagaimana keseluruhan proses kerja karyawan dalam mencapai target yang telah ditentukan perusahaan, kemajuan perkembangan karyawan yang diharapkan dapat mendukung rencana perusahaan di masa yang akan datang dan dalam pertemuan ini juga membahas mengenai kompensasi yang terkait dengan hasil dari kinerja karyawan (Aguinis, 2014).

6. Performance renewal and recontracting

Pada tahap ini menggunakan pandangan dan informasi dari tahapan dalam proses manajemen kinerja yang lain. Dalam tahap ini akan dilihat keseluruhan proses manajemen kinerja dan hasilnya serta apakah proses tersebut sudah berjalan dengan baik atau belum serta untuk melihat apakah terdapat kekurangan dalam proses-proses manajemen kinerja (Aguinis, 2014).

\section{METODOLOGI PENELITIAN}

\section{Jenis dan Metode Penelitian}

Jenis penelitian yang digunakan dalam penelitian ini adalah applied research. Applied research merupakan penelitian yang menyangkut aplikasi teori untuk dapat memecahkan suatu masalah tertentu dalam suatu organisasi/perusahaan. Menurut Sekaran (2010) tujuan utama dalam applied research adalah untuk pemecahan masalah, sehingga hasil penelitian dapat digunakan untuk kepentingan baik secara individu, organisasi, atau bahkan industry.

Sedangkan metode pengumpulan data yang digunakan dalam penelitian ini adalah gabungan metode kuantitatif dengan cara survei menggunakan kuesioner yang dimodifikasi dari model kuesioner Weis dan Hurtle (1997) mengenai persepsi karyawan terhadap sistem manajemen 
kinerja dan metode kualitatif dengan menggunakan wawancara mendalam.

\section{Unit Analisis}

Menurut Hamidi (2005) unit analisis merupakan satuan yang diteliti yang bisa merupakan individu, kelompok, benda, atau suatu latar peristiwa. Dalam penelitian ini, yang menjadi unit analisis adalah organisasi, yaitu perusahaan PT. XYZ.

\section{Kerangka Penelitian}

Berikut di bawah ini pada Gambar 2 akan dijelaskan mengenai kerangka penelitian rancangan penyempurnaan sistem manajemen kinerja di PT. XYZ.

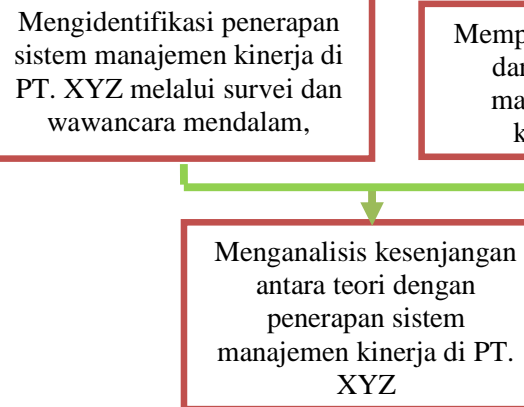

Gambar 2: Kerangka Penelitian

\section{Penentuan Sampel dan Narasumber}

Populasi penelitian ini adalah seluruh karyawan kantor pusat PT. XYZ yang berjumlah 315 orang. Pendekatan yang digunakan dalam kedua metode pengumpulan data dalam penelitian ini adalah non-probability sampling, dengan jenis sampel yang digunakan adalah purposive sampling sebanyak 104 responden untuk survei dan 3 narasumber untuk wawancara mendalam.

\section{Metode, Alat dan Pengolahan Data}

Berikut di bawah ini akan dijelaskan mengenai metode pengumpulan data, alat pengumpulan data dan pengolahan data pada Tabel 1 . 
Tabel 1 Metode Pengumpulan Data

\begin{tabular}{|c|c|c|c|c|}
\hline $\begin{array}{c}\text { Metode } \\
\text { Pengumpula } \\
\text { n Data }\end{array}$ & $\begin{array}{c}\text { Alat } \\
\text { Pengumpul } \\
\text { an Data }\end{array}$ & $\begin{array}{l}\text { Pengolahan } \\
\text { Data }\end{array}$ & Sumber Info & Tujuan \\
\hline \multirow{3}{*}{ Wawancara } & \multirow{3}{*}{$\begin{array}{l}\text { Pedoman } \\
\text { Wawancara }\end{array}$} & \multirow{3}{*}{$\begin{array}{l}\text { 1. Pembuatan } \\
\text { verbatim } \\
\text { 2. Reduksi } \\
\text { data dan } \\
\text { kata kunci } \\
\text { 3. Penarikan } \\
\text { kesimpulan. }\end{array}$} & $\begin{array}{l}\text { Direktur } \\
\text { SDM }\end{array}$ & $\begin{array}{l}\text { Mengetahui visi, misi, nilai dan } \\
\text { arahan strategi bisnis } \\
\text { perusahaan. }\end{array}$ \\
\hline & & & $\begin{array}{l}\text { General } \\
\text { Manager } \\
\text { SDM }\end{array}$ & $\begin{array}{l}\text { Mengkonfirmasi hasil temuan } \\
\text { data dari survei karyawan } \\
\text { mengenai penerapan manajemen } \\
\text { kinerja. }\end{array}$ \\
\hline & & & $\begin{array}{l}3 \text { orang } \\
\text { Manajer }\end{array}$ & $\begin{array}{l}\text { Merancang sistem manajemen } \\
\text { kinerja. Mengetahui sistem } \\
\text { manajemen kinerja di PT. XYZ. }\end{array}$ \\
\hline Survei & Kuesioner & $\begin{array}{l}\text { 1. Editing data, } \\
\text { 2. Coding } \\
\text { 3. Entry data, } \\
\text { 4. Cleaning } \\
\text { 5. Analisis data }\end{array}$ & $\begin{array}{l}\text { Seluruh } \\
\text { Supervisor } \\
\text { dan Staff }\end{array}$ & $\begin{array}{l}\text { Mengetahui persepsi karyawan } \\
\text { mengenai sistem manajemen } \\
\text { kinerja yang diterapkan di } \\
\text { perusahaan. }\end{array}$ \\
\hline $\begin{array}{l}\text { Studi } \\
\text { Literatur }\end{array}$ & & & $\begin{array}{l}\text { Buku dan } \\
\text { Jurnal }\end{array}$ & $\begin{array}{l}\text { Sebagai panduan dalam } \\
\text { menyusun alat pengumpulan } \\
\text { data. Memahami teori } \\
\text { manajemen kinerja. Menyusun } \\
\text { rancangan sistem manajemen. }\end{array}$ \\
\hline
\end{tabular}

\section{HASIL IDENTIFIKASI PERSEPSI KARYAWAN TERHADAP PE- NERAPAN SISTEM MANAJEMEN KINERJA DI PT. XYZ}

Berikut di bawah ini akan dijelaskan mengenai temuan persepsi karyawan terhadap sistem manajemen kinerja di PT. XYZ berdasarkan dari hasil survei dan wawancara.

\section{Hasil Survei}

Data hasil survei diolah menggunakan SPSS 22 dengan mencari nilai mean sebesar 3,20 dijadikan sebagai data nilai minimum penilaian suatu kondisi yang dinyatakan baik. Nilai tersebut diperoleh dari perhitungan $80 \%$ dari nilai maksimum yaitu 4 (Veithzal, 2005).

Secara keseluruhan nilai rata-rata dari persepsi karyawan terhadap manajemen 
kinerja di PT. XYZ dengan menyatukan empat proses (perencanaan, pelaksanaan, penilaian, dan tindak lanjut) tersebut adalah 2,94, lebih kecil dari nilai standar. Dengan rincian masing-masing mean pada tiap proses manajemen kinerja dapat dilihat pada gambar 3 di bawah ini.

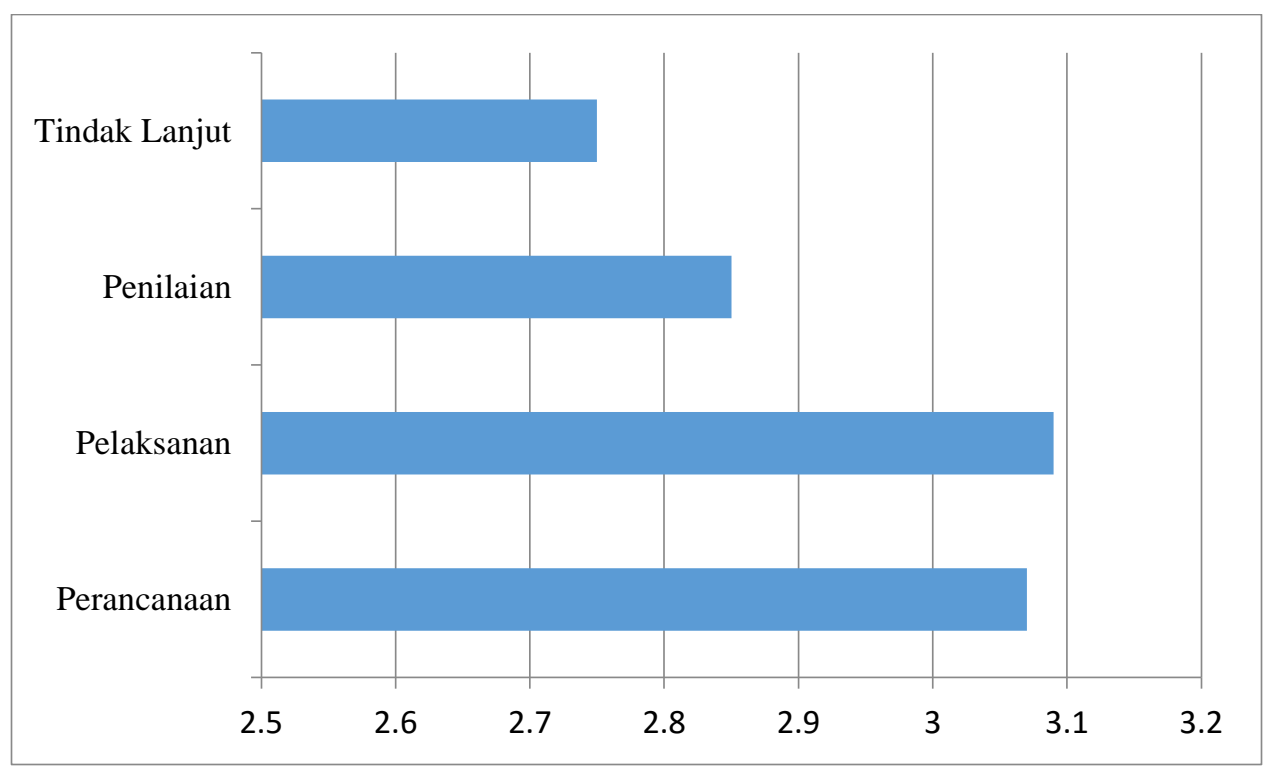

Gambar 3 Nilai Mean Survei Persepsi Karyawan Terhadap

Proses Manajemen Kinerja di PT. XYZ

Untuk lebih jelasnya mengenai hasil survei persepsi karyawan pada sistem manajemen kinerja, dapat dilihat pada grafik masing-masing proses manajemen kinerja di bawah ini.

a. Perencanaan Kinerja

Hasil survei persepsi karyawan mengenai proses perencanaan kinerja di PT. XYZ dapat dilihat pada gambar 4 di bawah ini.
Secara keseluruhan persepsi karyawan terhadap proses perencanaan kinerja di PT. XYZ menunjukan mean sebesar 3,07, dimana hasil tersebut menunjukan nilai dibawah standar. 
Dari gambar di bawah menunjukan terdapat beberapa kondisi kurang baik pada proses ini. Kondisi tersebut adalah kurangnya koordinasi atau komunikasi antara atasan dan bawahan dalam merencanakan kinerja, atasan kurang memahami mengenai pekerjaan yang dilakukan bawahannya, harapan kinerja karyawan kurang sejalan dengan perencanaan bisnis, karyawan kurang memahami hasil yang diharapkan dan target pencapaian kinerjanya, dan karyawan kurang memahami perilaku yang diharapkan untuk mencapai kinerja.

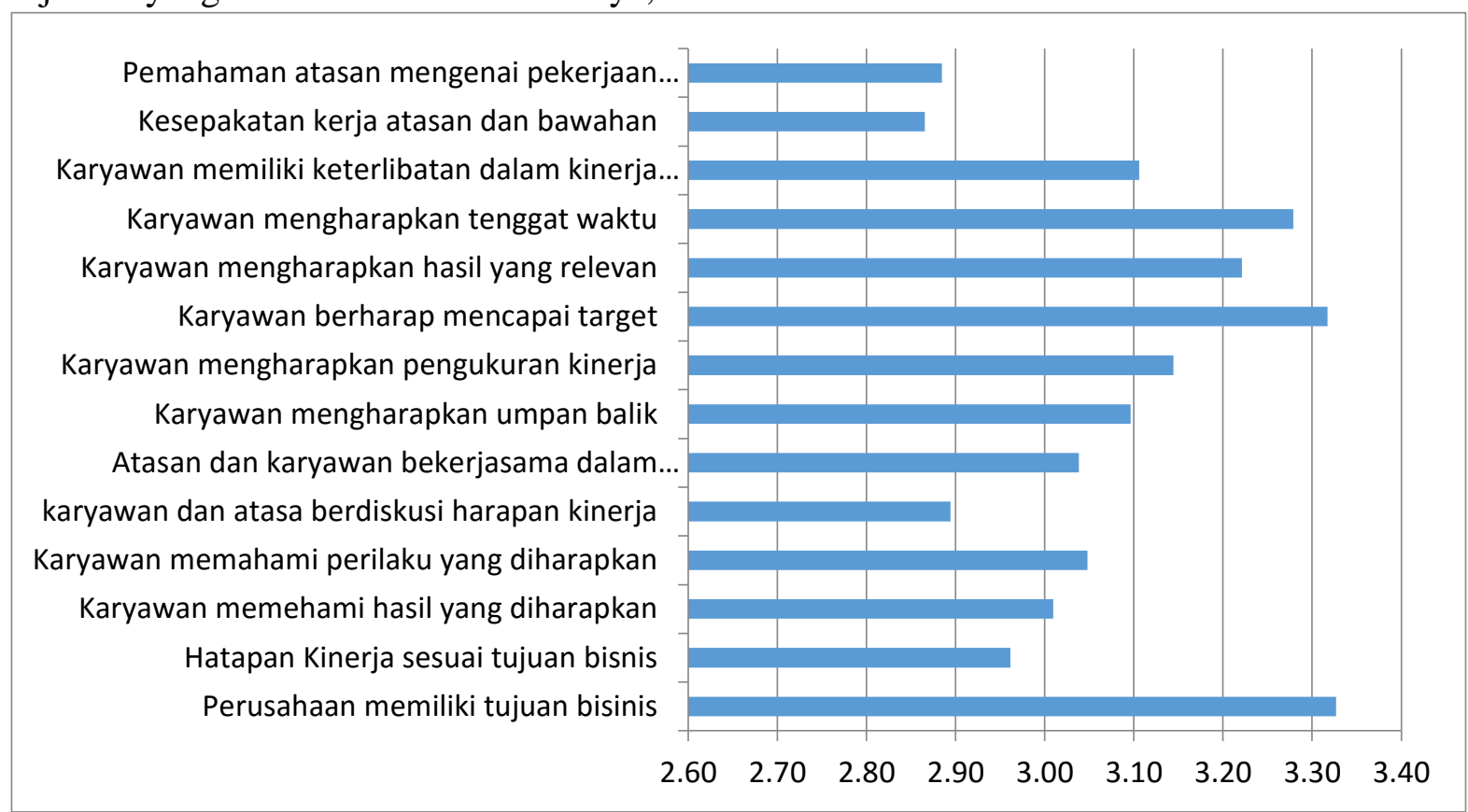

Gambar 4 Nilai Mean Survei Persepsi Karyawan atas

Perencanaan Kinerja di PT. XYZ

b. Pelaksanaan Kinerja

Hasil survei persepsi karyawan mengenai proses pelaksanaan kinerja di PT. XYZ dapat dilihat pada gambar 5 di bawah ini.

Secara keseluruhan persepsi karyawan terhadap proses pelaksanaan kinerja di PT. XYZ menunjukan mean sebesar 3,09, dimana hasil tersebut menunjukan nilai dibawah standar.

Dari gambar di atas menunjukan bahwa hampir seluruh kondisi pada pelaksanaan kinerja menunjukan angka yang kurang optimal. Kondisi kurang 


\section{Journal of Management Vol.13, No.1, January 2016: 88-106 and Business Review}

optimal tersebut diantaranya adalah diskusi yang dilakukan dengan atasan kurang efektif dalam mengarahkan kinerja, atasan kurang memberikan bisa mengerjakan tugas dengan baik, dan atasan kurang memberikan umpan balik terkait cara dan perilaku yang diharapkan untuk dapat mencapai kinerja yang

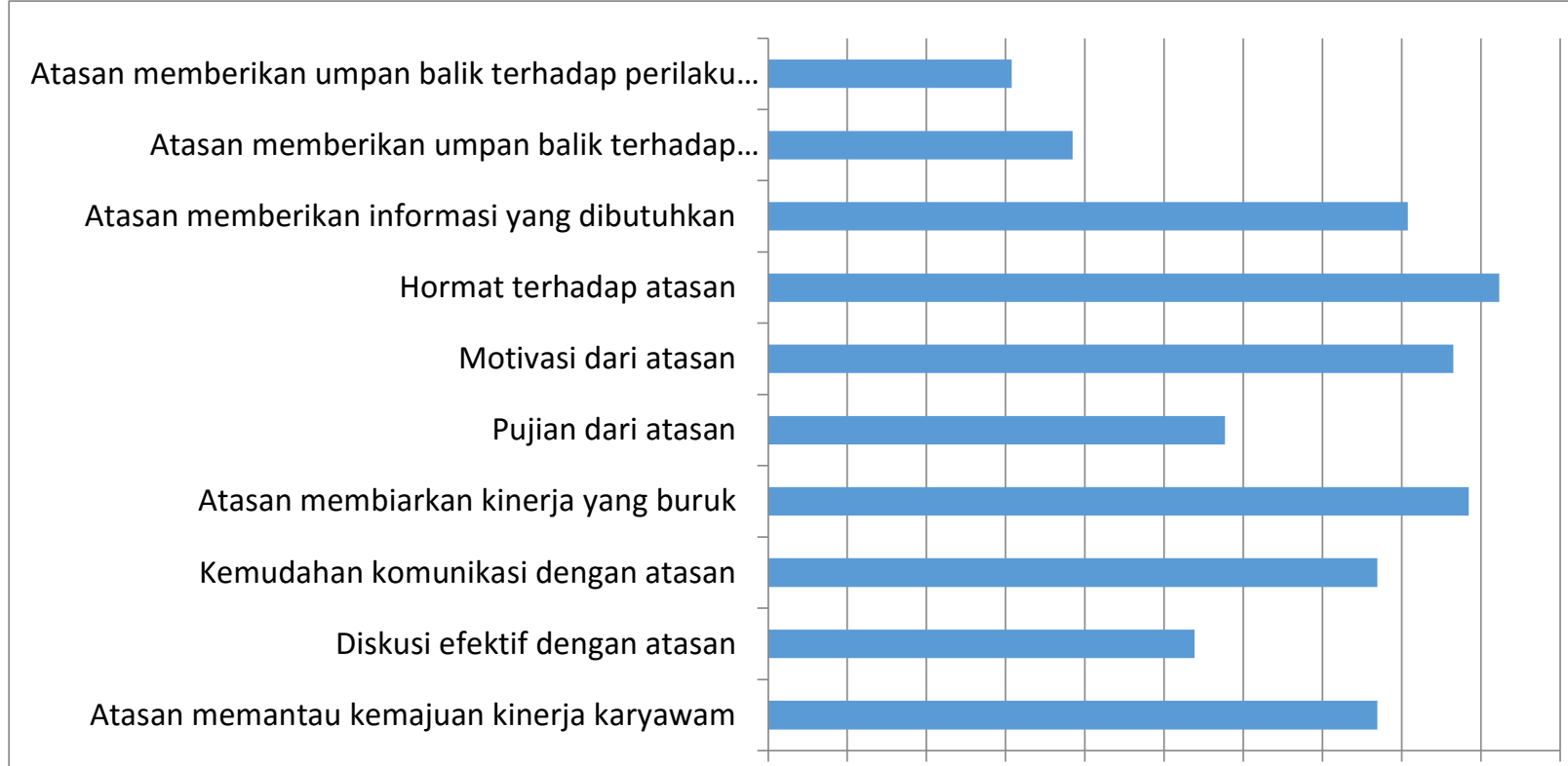

$\begin{array}{lllllllllll}2.75 & 2.80 & 2.85 & 2.90 & 2.95 & 3.00 & 3.05 & 3.10 & 3.15 & 3.20 & 3.25\end{array}$

penguatan atau pujian ketika bawahannya

diharapkan.

Gambar 5 Nilai Mean Survei Persepsi Karyawan atas

Pelaksanaan Kinerja di PT. XYZ

\section{c. Penilaian Kinerja}

Hasil survei persepsi karyawan mengenai proses penilaian kinerja di PT. XYZ dapat dilihat pada gambar 6 di bawah ini.

Secara keseluruhan persepsi karyawan terhadap proses penilaian kinerja di PT. XYZ menunjukan mean sebesar 2,85, dimana hasil tersebut lebih menunjukan nilai dibawah standar.

Dari gambar di atas menunjukan bahwa hampir seluruh kondisi pada penilaian kinerja menunjukan angka yang kurang optimal. Kondisi kurang optimal tersebut diantaranya adalah karyawan berpendapat bahwa perusahaan belum 


\section{Analisis Persepsi Karyawan ... (Maria K., Prasetya D., dan Dwi I.)}

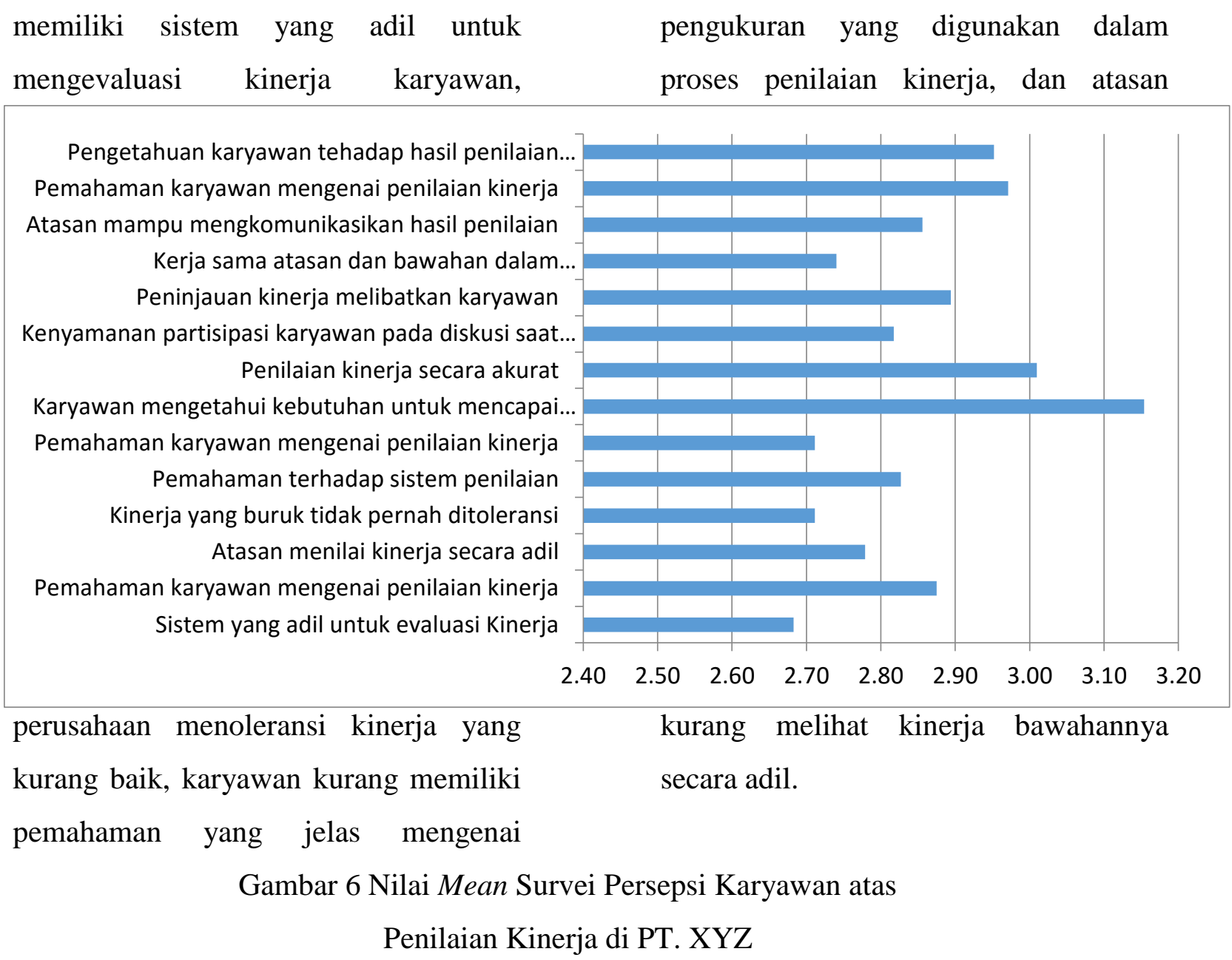

4. Tindak Lanjut Kinerja

Hasil survei persepsi karyawan mengenai proses tindak lanjut kinerja di PT. XYZ dapat dilihat pada gambar $7 \mathrm{di}$ bawah ini.

Secara keseluruhan persepsi karyawan terhadap proses tindak lanjut kinerja di PT. XYZ menunjukan mean sebesar 2,75, dimana hasil tersebut lebih menunjukan nilai di bawah standar.
Dari gambar di atas menunjukan bahwa hampir seluruh kondisi pada penilaian kinerja menunjukan angka yang kurang optimal. Kondisi kurang optimal tersebut diantaranya adalah karyawan berpendapat bahwa sistem penghargaan di perusahaan kurang adil, karyawan kurang mengerti mengenai sistem penghargaan di perusahaan, penghargaan yang didapat oleh keryawan kurang 


\section{Journal of Management Vol.13, No.1, January 2016: 88-106
and Business Review}

mencerminkan kinerja secara individu, dan sistem penghargaan yang ada saat ini kurang mendukung dari tujuan kinerja individu.

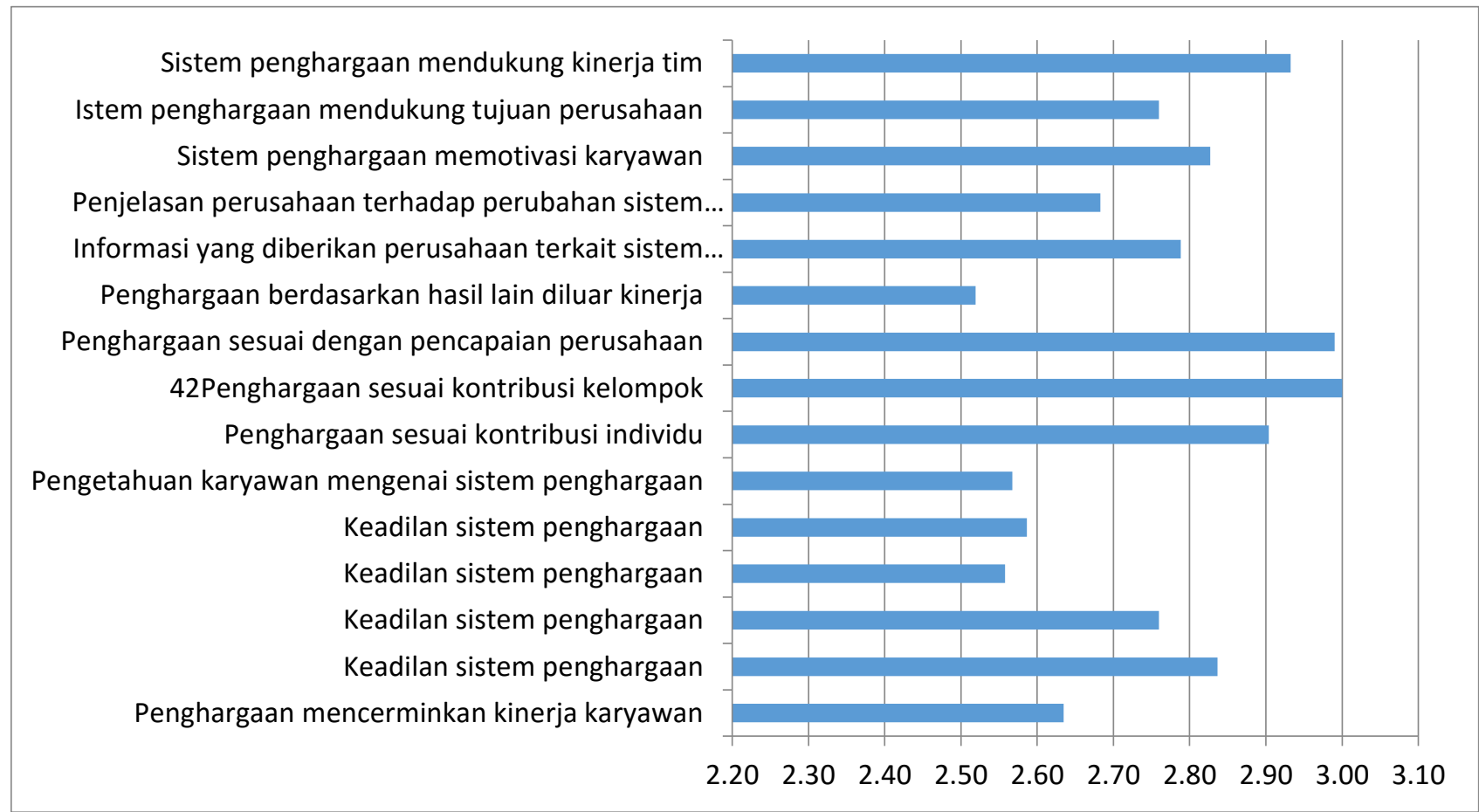

Gambar 7 Nilai Mean Survei Persepsi Karyawan atas

Tindak Lanjut Kinerja di PT. XYZ

\section{Hasil Wawancara Mendalam}

Hasil identifikasi wawancara mengenai persepsi karyawan terhadap penerapan sistem manajemen kinerja di PT. XYZ dapat dilihat pada tabel 2 berikut ini.

Tabel 2 Identifikasi Hasil Wawancara

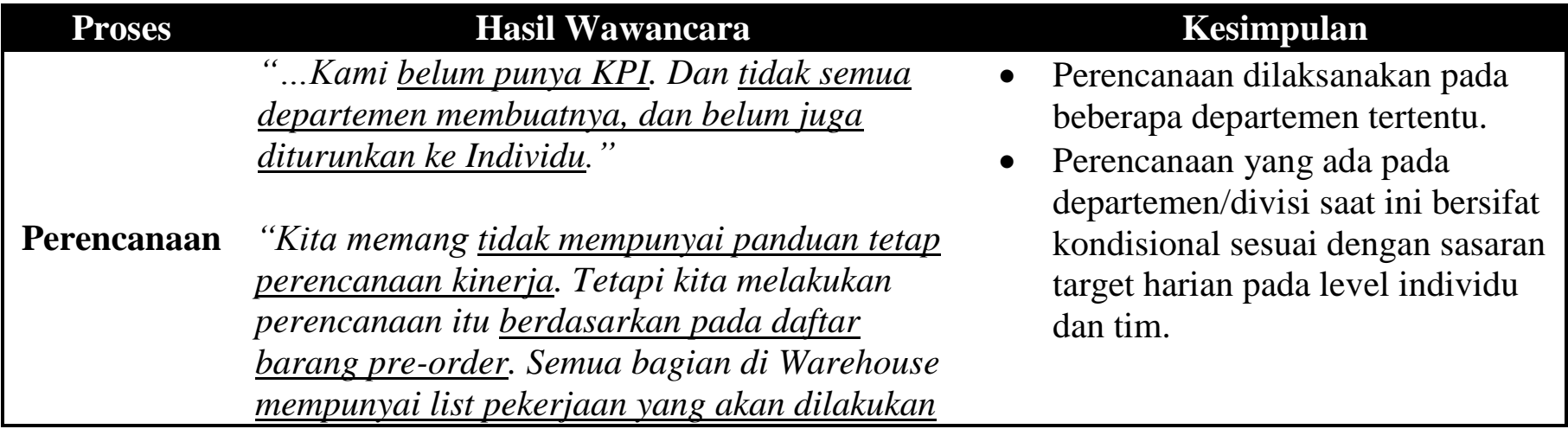




\begin{tabular}{|c|c|c|}
\hline & $\begin{array}{l}\text { berdasarkan kesepakatan dalam briefing harian } \\
\text { maupun metting bulanan." }\end{array}$ & $\begin{array}{l}\text { - Perencenaan kinerja yang disusun } \\
\text { tidak mempunyai format dan } \\
\text { pedoman yang khusus. }\end{array}$ \\
\hline Pelaksanaan & $\begin{array}{l}\text { "Kalau daily report yang ada saat ini itu } \\
\text { sekarang masih kurang, jadi kita cuma fokus } \\
\text { pada pending pekerjaan. Sedangkan kalau level } \\
\text { Spv itu ada laporan bulanan dimana dari } \\
\text { macam-macam jobdesk yang ada, dengan } \\
\text { targetnya bulan ini dia selesai atau tidak,." } \\
\text { "Beberapa departemen ada briefing dan } \\
\underline{\text { bagaimana memotivasi tim..." }} \\
\text { "Biasanya saya panggil dan pendampingan } \\
\text { personal. Kalau untuk memotivasi tim, kemarin } \\
\text { saya sudah minta orang training untuk } \\
\text { membantu memotivasi mereka. }\end{array}$ & $\begin{array}{l}\text { - Proses pelaksanaan kinerja di PT. } \\
\text { XYZ memiliki format dan } \\
\text { frekuensi pemantauan kinerja } \\
\text { yang berbeda. } \\
\text { - Komunikasi merupakan hal yang } \\
\text { penting untuk diterapkan karena } \\
\text { dapat meningkatkan motivasi } \\
\text { dalam bekerja. }\end{array}$ \\
\hline Penilaian & $\begin{array}{l}\text { "Kalau sekarang biasanya review atau evaluasi } \\
\text { itu setahun dua kali tuh. Kalau saya lagi } \\
\text { senggang biasanya sebulan dua bulan pasti saya } \\
\text { lakukan." } \\
\text { "Kalau dari direksi menilai kita itu dari closing } \\
\text { book" } \\
\text { "Iya, kita sebulan sekali mengadakan metting } \\
\text { bulanan berdasarkan pada hasil report harian } \\
\text { juga." }\end{array}$ & $\begin{array}{l}\text { Pada departemen/ divisi, } \\
\text { mekanisme penilaian yang } \\
\text { dilakukan bervariasi tergantung } \\
\text { pada target yang harus dicapai } \\
\text { setiap departemen/divisi. } \\
\text { Departemen/divisi mempunyai } \\
\text { kebijakan frekuensi penilaian } \\
\text { yang berbeda satu dengan } \\
\text { lainnya. }\end{array}$ \\
\hline $\begin{array}{l}\text { Tindak } \\
\text { Lanjut }\end{array}$ & 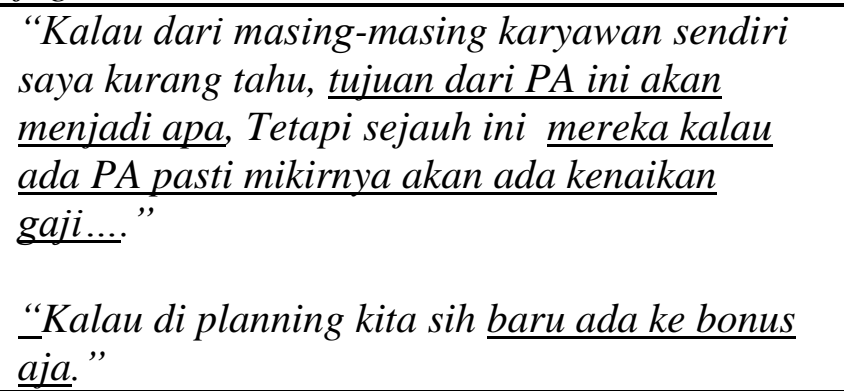 & $\begin{array}{l}\text { - Tindak Lanjut dari penilaian } \\
\text { kinerja yang digunakan dalam PT } \\
\text { XYZ adalah untuk menentukan } \\
\text { bonus karyawan. }\end{array}$ \\
\hline
\end{tabular}


5. ANALISIS KESENJANGAN

PENERAPAN SISTEM

MANAJEMEN KINERJA PT.

XYZ

Berdasarkan dari hasil identifikasi

dari hasil wawancara dan survei, maka selanjutnya data tersebut akan dianalisis dengan membandingkan dengan teori, sehingga didapat kesenjangan antara penerapan sistem manajemen kinerja di PT. $\mathrm{XYZ}$ dengan teori sistem manajemen kinerja yang dapat dilihat pada tabel 3 di bawah ini.

Tabel 3 Analisis Kesenjangan

\begin{tabular}{|c|c|c|c|}
\hline Proses & Teori Manajemen Kinerja & Rekapitulasi Temuan & Kesenjangan \\
\hline Perencanaan & $\begin{array}{l}\text { - Melakukan kesepakatan } \\
\text { perencanaan kinerja (membahas } \\
\text { dan mengidentifikasi hasilnya) } \\
\text { antara atasan dengan bawahan } \\
\text { yang biasanya dilakukan pada } \\
\text { awal tahun. } \\
\text { - Mendefinisikan: } \\
\text { - Tanggung jawab utama (KRA) } \\
\text { - Indikator kinerja (KPI) } \\
\text { - Target } \\
\text { - Standar kinerja } \\
\text { - Bobot } \\
\text { - Tujuan hasilnya harus SMART } \\
\text { (specific, measurable, attainable, } \\
\text { reasonable, time. }\end{array}$ & $\begin{array}{l}\text { - Perusahaan belum } \\
\text { menetapkan perencanaan } \\
\text { yang selanjutnya akan } \\
\text { bersinergi dengan tujuan } \\
\text { perusahaan. } \\
\text { - Tidak adanya } \\
\text { perencanaan kinerja yang } \\
\text { dimulai dari penetapan } \\
\text { target, indikator } \\
\text { pencapaian dari level } \\
\text { perusahaan sampai level } \\
\text { individu. } \\
\text { - Kurangnya komunikasi } \\
\text { antara atasan dan } \\
\text { bawahan dalam } \\
\text { merencanakan kinerja } \\
\text { karyawan. }\end{array}$ & $\begin{array}{l}\text { - Tidak adanya media yang } \\
\text { memfasilitasi kesepakatan } \\
\text { antara atasan dan bawahan } \\
\text { mengenai perencanaan } \\
\text { kinerja. } \\
\text { - Proses perencanaan kinerja } \\
\text { belum cukup optimal } \\
\text { karena tidak memiliki } \\
\text { dokumentasi tertulis } \\
\text { mengenai komponen } \\
\text { utama perencanaan } \\
\text { kinerja, yang terdiri dari: } \\
\text { - Tanggung jawab utama } \\
\text { (KRA) } \\
\text { - Indikator kinerja (KPI) } \\
\text { - Target } \\
\text { - Standar kinerja } \\
\text { - Bobot }\end{array}$ \\
\hline Pelaksanaan & $\begin{array}{l}\text { Pelaksanaan kinerja merupakan } \\
\text { komunikasi yang sedang } \\
\text { berlangsung antara manajer dan } \\
\text { bawahan } \\
\text { - Atasan melakukan coaching, } \\
\text { mentoring, konseling, observasi, } \\
\text { feedback, punishment dan } \\
\text { reinforcement. } \\
\text { - Memperkuat dan mendukung } \\
\text { antara atasan dan bawahan dalam } \\
\text { upaya untuk mengejar tujuan } \\
\text { sepanjang tahun dengan }\end{array}$ & $\begin{array}{l}\text { - Sudah adanya komunikasi } \\
\text { antara atasan dan } \\
\text { bawahan dalam } \\
\text { pelaksanaan kinerja, } \\
\text { namun komunikasi yang } \\
\text { efektif antara atasan } \\
\text { dengan bawahan untuk } \\
\text { saling mendukung dan } \\
\text { memotivasi dalam } \\
\text { pencapaian target kinerja } \\
\text { kurang efektif. }\end{array}$ & $\begin{array}{l}\text { - Komunikasi (proses } \\
\text { coaching, mentoring/ } \\
\text { konseling) yang kurang } \\
\text { efektif antara atasan dan } \\
\text { bawahan dalam } \\
\text { pelaksanaan kinerja. }\end{array}$ \\
\hline
\end{tabular}


Analisis Persepsi Karyawan ... (Maria K., Prasetya D., dan Dwi I.)

\begin{tabular}{|c|c|c|c|}
\hline Proses & Teori Manajemen Kinerja & Rekapitulasi Temuan & Kesenjangan \\
\hline & $\begin{array}{l}\text { menggunakan alat komunikasi } \\
\text { sebagai bukti dan pencapaian } \\
\text { kinerja karyawan. }\end{array}$ & & \\
\hline Penilaian & $\begin{array}{l}\text { Dilakukan secara periodik: semi- } \\
\text { annual / quarterly } \\
\text { - Memiliki metode penilaian kinerja } \\
\text { - Memiliki formulir penilaian } \\
\text { kinerja yang terdiri dari } 8 \\
\text { komponen utama, dan } 8 \\
\text { karakteristik utama. }\end{array}$ & $\begin{array}{l}\text { - Karyawan kurang } \\
\text { memahami indikator yang } \\
\text { dinilai pada saat proses } \\
\text { penilaian kinerja. } \\
\text { - Tidak adanya pedoman } \\
\text { penilaian kinerja yang } \\
\text { sama pada masing-masing } \\
\text { divisi/ departemen. Baik } \\
\text { itu dari waktu, frekuensi, } \\
\text { hingga alat/metode yang } \\
\text { digunakan dalam } \\
\text { penilaian kinerja. }\end{array}$ & $\begin{array}{l}\text { - Proses penilaian kinerja di } \\
\text { perusahaan belum cukup } \\
\text { optimal, karena: } \\
\text { - Frekuensi/periode } \\
\text { penilaian kinerja yang } \\
\text { berbeda pada tiap divisi/ } \\
\text { departemen. } \\
\text { - Formulir penilaian kinerja } \\
\text { yang ada belum sesuai } \\
\text { dengan komponen dan } \\
\text { karakteristik formulir } \\
\text { penilaian kinerja. }\end{array}$ \\
\hline $\begin{array}{l}\text { Tindak } \\
\text { Lanjut }\end{array}$ & $\begin{array}{l}\text { - Adanya pedoman tindak lanjut } \\
\text { dari penilaian kinerja. } \\
\text { - Adanya sistem penghargaan, baik } \\
\text { itu pola karir, imbal jasa, ataupun } \\
\text { progam pelatihan dan } \\
\text { pengembangan. } \\
\text { - Pemberian penghargaan } \\
\text { berdasarkan dari kontribusi } \\
\text { karyawan terhadap pencapaian } \\
\text { target individu maupun tim. }\end{array}$ & $\begin{array}{l}\text { - Tindak lanjut hasil } \\
\text { penilaian kinerja } \\
\text { digunakan untuk sistem } \\
\text { bonus karyawan. } \\
\text { - Sosialisasi sistem } \\
\text { penghargaan di PT. XYZ } \\
\text { belum begitu jelas untuk } \\
\text { para karyawan. }\end{array}$ & $\begin{array}{l}\text { - Tindak lanjut kinerja } \\
\text { belum cukup optimal } \\
\text { karena belum adanya } \\
\text { pedoman tindak lanjut dari } \\
\text { penilaian kinerja, baik itu } \\
\text { untuk progam imbal jasa, } \\
\text { pelatihan dan } \\
\text { pengembangan, hingga } \\
\text { pola karir. }\end{array}$ \\
\hline
\end{tabular}

\section{IMPLIKASI MANAJERIAL}

Visi dari perusahaan dapat dicapai dengan meningkatkan segala macam sumber daya yang ada di perusahaan, salah satunya adalah sumber daya manusia. Salah satunya adalah melalui sistem yang mampu menilai dan meningkatkan kinerja karyawan, yang biasa disebut dengan istilah manajemen kinerja (performance management). Berdasarkan teori yang dikemukakan oleh Aguinis (2014) dalam meningkatkan kinerja perusahaan suatu perusahaan harus mampu terlebih dahulu meningkatkan kinerja para karyawannya. Selain itu, Aguinis (2014) juga menambahkan bahwa manajemen kinerja harus mencakup aspek proses yang berkelanjutan dan berkaitan dengan tujuan strategis.

Implikasi manajerial atau implikasi praktis yang dapat dilakukan oleh pihak 


\section{Journal of Management
and Business Review Vol.13, No.1, January 2016: 88-106}

PT. XYZ ini dapat berfokus pada penyempurnaan pada setiap masingmasing tahapan proses sistem manajemen kinerja. Dari penelitian ini ditemukan bahwa secara keseluruhan sistem manajemen kinerja menunjukan kondisi yang lemah pada proses perencanaan, pelaksanaan, penilaian dan tindak lanjut. Sistem manajemen kinerja bisa dikatakan sebuah sistem yang stratejik dalam menjalankan bisnis perusahaan. Sistem manajemen kinerja yang berhasil akan menciptakan komitmen karyawan untuk dapat meningkatkan kinerja individu. Oleh karena itu, PT. XYZ perlu melakukan penyempurnaan pada setiap tahapan proses sistem manajemen kinerja yang kurang optimal ini agar bisa mencapai visi perusahaan.

Seperti yang telah disinggung sebelumnya, sistem manajemen kinerja PT. XYZ yang lemah dimulai dari perencanaan kinerja. Pada proses ini ditemukan adanya ketidakjelasan kesepakatan kerja antara atasan dan bawahan mengenai apa yang haru dilakukan dan bagaimana cara mereka menjalankan pekerjaan. Maka dari itu maka dalam proses perencanaan kinerja ini perlu melihat visi, misi, nilai, dan strategi perusahaan, sehingga seluruh stakeholder dalam perusahaan mengertu dan tahu apa dan bagaimana yang harus mereka lakukan dalam pekerjaan agar bisa mencapai tujuan perusahaan.

Hal tersebut juga berlanjut pada pelaksanaan kinerja. Kondisi lemah pada proses ini disebabkan oleh komunikasi yang kurang efektif antara atasan dan bawan dalam melakukan pemantauan kinerja. Tanggung jawab utama seorang atasan pada proses pelaksanaan ini adalah selain selain melakukan observasi dan membuat dokumentasi adalah memberikan updates, feedback, resources dan reinforcemen. Oleh karena itu, perlu adanya membangun relasi yang baik antara atasan kepada bawahan, sehingga atasan tahu, paham dan memiliki metode coaching, mentoring, serta counceling yang baik dan seharusnya kepada masing-masing bawahan yang dikelola.

Hal tersebut juga terjadi pada proses penilaian kinerja. Kondisi lemah pada proses ini disebabkan oleh ketidakpahaman karyawan terhadap indikator yang dinilai, sehingga sering 
terjadi subjektifitas hasil penilaian. Pada proses ini baik pihak karyawan maupun pihak atasan bertanggung jawab terhadap proses penilaian dan evaluasi untuk mengetahui sejauh mana tujuan yang ditargetkan sudah tercapai dan bagaimana proses untuk sampai kepada target tersebut serta bagaimana perilaku yang ditunjukkan. Oleh karena itu, perlu adanya training for rater dan penetapan metode penilaian seperti penlaian terbuka atau tertutup dengan menggunakan alat seperti $360^{\circ}$, self rating, serta penilaian top-down atau sebaliknya. Hal ini ditujukan agar seorang atasan sudah tahu apa yang harus dinilai dan dicapai dan menghindari subjektifitas penilaian.

Kondisi lemah juga terjadi pada proses tahapan tindak lanjut. Kondisi lemah tersebut disebabkan oleh ketidakpahaman karyawan terhadap sistem tindak lanjut kinerja. Karyawan tidak mengerti apa yang menjadi kelanjutan dari hasil penilaian kinerja. Saat ini di perusahaan sudah diterapkan sistem penghargaan financial berupa bonus. Selain tindak lanjut financial, pada tahap ini juga perlu sistem tindak lanjut non-financial dari hasil penilaian kinerja. Seperti sistem pelatihan dan pengembangan, career path, rotasi, maupun promosi jabatan.

\section{KESIMPULAN DAN SARAN}

Secara keseluruhan berdasarkan dari hasil survei dan wawancara mendalam lalu dibandingkan dengan teori, ditemukan bahwa sistem manajemen kinerja di PT. XYZ cukup lemah pada masing-masing tahapan proses sistem manajemen kinerja. Lemahnya sistem manajemen kinerja pada suatu perusahaan bisa berdampak pada tidak tercapainya tujuan perusahaan, karena tidak adanya suatu sistem yang mengelola serta memantau kinerja karyawan.

Berdasarkan hasil tersebut, maka diperlukan penyempurnaan pada masingmasing tahapan proses sistem manajemen kinerja di PT. XYZ untuk bisa membantu perusahaan mewujudkan tujuan perusahaan. Selain itu, penting bagi perusahaan untuk secara konsisten dan berkala melakukan komunikasi dan sosialisasi terhadap semua aspek pada proses penilaian kinerja sehingga manajemen kinerja menjadi suatu budaya 


\section{Journal of Management Vol.13, No.1, January 2016: 88-106 and Business Review}

kerja yang mampu mendorong kinerja

perusahaan. 
Analisis Persepsi Karyawan ... (Maria K., Prasetya D., dan Dwi I.)

\section{DAFTAR PUSTAKA}

Aguinis, Herman. (2014). Performance Management 3rd Edition. New Jersey: Pearson.

Aydin, Bulent. (2010). A Research Analysis on Employee Satisfaction in terms of Organizational Culture and Spiritual Leadership. International Journal Business and Management Vol. 4 No. 3.

Badan Pusat Satistik. 2011. Pengeluaran Untuk Konsumsi Masyarakat Indonesia Tahun 2011. Jakarta: Badan Pusat Statistik.

Brudan, A. Rediscovering Performance Management System, Learning, and Integration. Measuring Busines Excellence. Camines: E. G.

Hamidi. 2005. Metode Penelitian Kualitatif: Aplikasi Praktis Pembuatan Proposal Dan Laporan Penelitian. Malang: UMM PRES.

Havard Business Review. (2013). A Report By Harvard Business Review Analytic Services:

The Impact of Employee Engagement on Performance.Harvard Business School Publishing.

Management System. Makalah. Jakarta: Sekolah Tinggi Manajemen PPM.

Sekaran, Uma. (2010). Research Methods for Business. Grd Edition. USA: John Willey \& Sons, Inc.

Veithzal. 2005. Performance Appraisal. Edisi Pertama. Jakarta: Rajawali Pers.

Weiss, TB, dan Hartle, F. 1997 Reengineering Performance Management: Breakthroughs in Achieving Strategy Through People.St Lucie Press. 